\title{
The magnitude, diversity, and distribution of the economic costs of invasive terrestrial invertebrates worldwide
}

\section{David RENAULT}

Rennes 1 University: Universite de Rennes 1

\section{Elena ANGULO}

Universite Paris-Saclay

Ross Cuthbert ( $\nabla$ rossnoelcuthbert@gmail.com )

Helmholtz-Zentrum fur Ozeanforschung Kiel

Phillip J. HAUBROCK

Senckenberg Forschungsinstitut und Naturmuseum Frankfurt: Senckenberg Forschungsinstitut und Naturmuseum

\section{César CAPINHA}

University of Lisbon: Universidade de Lisboa

\section{Andrew M. KRAMER}

University of South Florida

Franck COURCHAMP

Universite Paris-Saclay

\section{Research Article}

Keywords: InvaCost, Arthropoda, Nematoda, Mollusca, Platyhelminthes, insect, monetary impact, nonnative, socioeconomic indicators, dollar

Posted Date: April 1st, 2021

DOl: https://doi.org/10.21203/rs.3.rs-215455/v1

License: (c) (i) This work is licensed under a Creative Commons Attribution 4.0 International License. Read Full License

Version of Record: A version of this preprint was published at Science of The Total Environment on April 1st, 2022. See the published version at https://doi.org/10.1016/j.scitotenv.2022.155391. 


\section{Abstract}

Invasive species are a major driver of global biodiversity loss, hampering conservation efforts and disrupting ecosystem functions and services. While accumulating evidence has documented ecological impacts of invasive species across major geographic regions, habitat types and taxonomic groups, appraisals for economic costs have remained relatively sparse. This has hindered effective cost-benefit analyses that inform expenditure on management interventions to prevent, control, and eradicate invasive species. Terrestrial invertebrates are a particularly pervasive and damaging group of invaders, with many species compromising primary economic sectors such as agriculture and health. The present study provides synthesised quantifications of economic costs caused by invasive terrestrial invertebrates on the global scale and across a range of descriptors, using the InvaCost database. Invasive terrestrial invertebrates reportedly cost the global economy US\$ 1.26 trillion over the investigated period (19602020), mostly due to invasive insects (>90\%). Overall, costs were not equally distributed geographically, with North America (76\%) reporting the greatest costs, with far lower costs reported in Europe (4\%) Asia (4\%), Africa (3\%), South America (2\%), and Oceania (1\%). These costs mostly resulted from direct resource damages and losses (76\%), particularly to agriculture and forestry; relatively little (4\%) was invested in management. A minority of monetary costs was directly observed (43\%), but costs were mostly sourced from highly reliable estimates (58\%). Economic costs displayed an increasing trend with time, with an average annual cost of US\$ 20.67 billion since 1960, but reporting lags reduced costs in recent years. The massive global economic costs of terrestrial invertebrates require urgent consideration and investment by policymakers and managers, in order to prevent and remediate the economic and ecological impacts of these and other invasive species groups.

\section{Introduction}

Invasive alien species (IAS) have massive adverse effects on biodiversity, ecosystem structure and functions (Blackburn et al. 2019). These impacts can result in cascading effects to ecosystem services (Pejchar and Mooney 2009) as well as human welfare through, for example, the vectoring of pathogens and parasites which cause diseases (Hulme et al. 2014; Medlock et al. 2015) or the health issues from reactions to stings and/or bites (e.g. Vinson 1997). By spreading and developing in a large variety of natural and anthropogenic habitats, IAS are also burgeoning stressors in several economic sectors (Diagne et al. 2020). Yet, despite increasing awareness of the burden generated by IAS, and legislation aimed at limiting their threats to biodiversity and ecosystem functioning, our capacity to contain invasions has often remained weak (Early et al. 2016). While IAS monitoring and management efforts have progressively increased over the past years in protected areas (but see Liu et al. 2020; Rico-Sánchez et al. 2020), resource allocations for biosecurity and post-invasion management are generally made ad hoc in many areas (Liebhold and Kean 2019). The paucity, or even absence for certain IAS, of quantified socioeconomic costs incurred by invasions (see Lodge et al. 2016 and references therein) likely contributes to explaining these reduced investment incentives. Accordingly, awareness about the economic costs of IAS is increasingly recognized as critical to strengthen the rationale for policymaking 
and for better-informed decisions (Leung et al. 2002; Caffrey et al. 2014; Hoffmann and Broadhurst 2016; Diagne et al. 2020).

Pimentel et al. $(2000,2005)$, and later Kettunen et al. (2009), were among the first attempts to summarize the large-scale (i.e., regional or national) costs, in monetary terms, of IAS. These studies had the benefit of pointing out the huge costs associated with IAS, which until then had remained unquantified. However, the acknowledged difficulties in monetizing some types of costs, in particular those not directly linked to primary economic activities, such as alterations of ecosystem services, and to standardize very different costs, resulted in important shortcomings in the presented figures (see Hoagland and Jin 2006; Hoffmann and Broadhurst 2016). The accounting of all types of impacts is critical for capturing the full dimension of invasion costs, which can facilitate evidence-based decision-making. Underestimated figures can, for example, mislead decision makers into a lower allocation of resources than what is actually warranted, or vice-versa (Lovell et al. 2006; Marbuah et al. 2014), and thus cause an inefficient prioritization of management efforts. Such quantifications should pay particular attention to taxonomic groups known to cause disproportionate economic impact and losses, such as insects (e.g. Bradshaw et al. 2016; Paini et al. 2016). This knowledge would facilitate monetary comparisons of cost types between resource damages and invasion management.

Terrestrial invertebrates include several IAS that have been described as major economically damaging taxa. For example, termites compromise infrastructure (Buczkowski and Bertelsmeier 2017), and many ant species alter ecosystem structure and function (Holway et al. 2002; Bertelsmeier et al. 2015; Wong et al. 2020). We suggest that this economic burden might have risen steadily along with the significant increase in establishment of alien terrestrial invertebrate species reported in the literature over past decades (Roques et al. 2009; Roques 2010; Seebens et al. 2017). Several invasive invertebrates, in particular insects, also greatly affect biodiversity, with critical consequences for native species (Lebouvier et al. 2020; Liu et al. 2020). Predictions of future range shifts that accompany globalization and climate change will likely add to these effects (Bebber et al. 2013; Bellard et al. 2013; Bertelsmeier et al. 2015). At the same time, there remains a significant lack of information on economic costs caused by invasive terrestrial invertebrates other than insects, which early estimation was of US\$70 billion per year in goods and services damages globally (Bradshaw et al. 2016). Some well-known examples of damaging invasive invertebrate groups other than insects include terrestrial gastropods (Cowie et al. 2008), earthworms (Hendrix 2006) or flatworms (Sugiura 2010). Nevertheless the overall economic costs of these taxa and of invasive terrestrial invertebrates have not been assessed so far.

Here, we use the recently developed InvaCost database (Diagne et al. 2020) to provide a global-scale assessment of the reported economic costs of invasive terrestrial invertebrates. Recent works using the InvaCost database have highlighted economic impacts at regional and country scales (e.g., Haubrock et al. in press a; Heringer et al. in press; Kourantidou et al. in press; Liu et al. in press). Yet, the effects of many widespread invasive taxa remain unquantified at the global scale using these novel comprehensive data. This is the case for invasive terrestrial invertebrates, for which the types of costs caused, economic sectors affected, and the geographical patterns and temporal trends of these costs remain largely 
unassessed. To address this important knowledge gap, we analyse the InvaCost database to examine how monetary costs of invasive terrestrial invertebrates are distributed across taxonomic groups, geographic regions, cost types and socioeconomic sectors. Moreover, we model the global temporal trends in these reported economic costs over recent decades.

\section{Methods}

\section{Data extraction}

To estimate the economic costs of terrestrial invertebrate invasions, we considered data from the InvaCost database (9,823 entries; InvaCost v.3.0; Diagne et al. 2020; Angulo et al. in press; https://doi.org/10.6084/m9.figshare.12668570). This database was developed to provide standardised quantification of the costs caused by invasive species worldwide, including extensive information about the nature of these costs. Grey and published references were retrieved from standardised searches in online repositories (ISI Web of Science, Google Scholar and Google search engine), opportunistic collection based on targeted searches, and contacting experts/stakeholders to request documents or files containing cost information. Gathered references were thoroughly examined to assess relevance, and then scrutinized for collating cost estimates associated with invasive species. Every cost entry was recorded with > 60 parameters (Online Resource 1, Tab_1 "Descriptors"), double checked by one or two independent experts, and finally converted to a common currency (US dollars (US\$) 2017; see Diagne et al. 2020 for detailed information).

The extraction and analysis of cost data from the InvaCost database were performed using the "invacost" package v0.3-4 (Leroy et al. 2020) in R v4.0.2 (R Core Team 2020). To specifically examine terrestrial invertebrates, a two-step filtering process was performed. First, we selected the 'Terrestrial' category (Online Resource 1, Tab_2 "DatasetTerrestriallnvertebrates", column V "Environment_IAS" of the database), and second, we kept only 'Arthropoda', 'Mollusca', 'Platyhelminthes' and 'Nematoda' taxa (Online Resource 1, Tab_2 "DatasetTerrestriallnvertebrates", column "Phylum”). In doing so, we excluded any terrestrial species which have an aquatic life history stage (for instance, mosquitoes which are categorised as 'Semi-aquatic'), or those that are associated with water for foraging and/or reproduction. These costs are presented elsewhere (Cuthbert et al. in press a). Whenever a cost was reported for a combination of more than one category in the column "Geographic region" or taxonomy below "Phylum", we changed these data to 'Diverse/Unspecified'. Collated data comprised a total of 1,109 entries (Online Resource 1, Tab_2 "DatasetTerrestriallnvertebrates"). However, because the temporal extent of these reported costs varied considerably across records (i.e., infra-year, single year and multi years), we used the expandYearlyCosts function of the "invacost" R package to obtain comparable annual costs for all cost estimates (Leroy et al. 2020). In brief, this function provides annualised cost estimates for all entries, based upon the time range represented in the original cost data (Diagne et al. 2020; https://doi.org/10.6084/m9.figshare.12668570 , and Online Resource 1, Tab_1 "Descriptors"). We based this on the difference between the starting (Online Resource 1, Tab_2 "DatasetTerrestriallnvertebrates", column "Probable starting year adjusted") and ending (Online Resource 1, Tab_2 
"DatasetTerrestriallnvertebrates", column "Probable ending year adjusted") years of the reported costs. For example, a cost of $\$ 100,000$ spanning 10 years would be expanded to $\$ 10,000$ per year. When no period of impact was specified in one and/or the other column(s), we counted only a single year (even though the cost might have been repeated over many years, even up to the present time). This resulted in 4,005 expanded entries (i.e. per year) from the initial 1,109 entries.

\section{Cost description}

The invasion costs totals were examined according to different descriptors of the costs that were available in the database (Online Resource 1, Tab_1 "Descriptors"). First, we focused in the geographic region where the cost occurred, the type of cost and the economic sector impacted. For the type of cost, we used two columns: (i) the "Type of cost merged" column that categorized the cost in "Damage" referring to damages or losses incurred by invasion (i.e., costs for damage repair, resource losses, medical care), "Management" comprising control-related expenditure (i.e., monitoring, prevention, control, eradication), and "Mixed" including mixed damage and management costs (cases where reported costs were not clearly distinguished); every cost for which the exact nature of cost was not clearly defined was assigned to "Unspecified"; (ii) the "Management type" column, which differentiates among pre- and postinvasion management expenditures, and actions including research or funding for invasive species, or mixed actions. For the economic sector that was impacted by the cost (activity, societal or market sector), we used the column "Impacted sector" (Online Resource 1, Tab_3 "ImpactedSector"); individual cost entries not allocated to a single sector were re-assigned to a new category called "Mixed".

The column "Implementation" was used to distinguish whether the cost estimate was actually realised ("Observed") or whether it was expected ("Potential"), and we used the column "Method reliability", which illustrates the perceived reliability of cost estimates based on the type of publication and method of estimation. Estimates in peer-reviewed publications or official reports, or with documented, repeatable and/or traceable methods were designated as "High" reliability (hereafter, "reliable"); all other estimates were designated as "Low" reliability (Diagne et al. 2020, and Online Resource 1, Tab_1 "Descriptors").

\section{Temporal trends}

We estimated global average annual costs of terrestrial invertebrate invaders represented in the InvaCost database by quantifying the temporal trends in cost accumulation. We performed these estimates from 1960 to 2020; monetary exchange rates could not be obtained from official institutions (e.g. World Bank) prior to 1960. We accounted for effects of time lags between the occurrence of the costs and their reporting in analysed documents through the examination of the "Impact year" column relative to the "Publication year" within the terrestrial invertebrate subset of the expanded database (Online Resource 1, Tab_2 "DatasetTerrestriallnvertebrates"). Examination of quantiles from this relationship indicated that years following 2013 were still too incomplete ( $<5 \%$ ), and we thus excluded those years from temporal analyses. Then, a range of regression modelling techniques was applied to examine the temporal dynamics of reported costs (modelCosts function in "invacost" R package, Leroy et al. 2020), including linear/robust regressions (linear and quadratic terms), multivariate adaptive regression Splines (MARS), 
generalised additive models (GAM) and quantile regression (quantiles $0.1,0.5,0.9$ ). This range of modelling approaches was selected to account for issues related to econometric data, such as heteroskedasticity and presence of outliers, allowing for selection among several linear and non-linear models. We used the root mean square error (RMSE) to examine and compare model fits.

\section{Results}

\section{Geographic distribution of the costs incurred by terrestrial invertebrates}

The collective costs of the 4,005 expanded entries for terrestrial invertebrates amounted to US\$1.26 trillion over the period of 1960 to 2020 . From these, less than half of the costs (43\%; US\$ 545.92 billion; $n$ $=2,215$ expanded entries) were empirically observed, rather than predicted using costs from a small area to extrapolate to a broader scale or expected from extending an existing impact over time. However, highly reliable costs dominated (58\%; US\$ 733.62 billion; $n=2,973$ ) (Fig. 1 ).

Globally, the majority of reported costs were from North America ( $n=1,848$; US\$ 956.33 billion), followed by Europe ( $n=631$; US 54.87 billion), Asia with US $\$ 46.34$ billion $(n=386)$, Africa $(n=362 ;$ US $\$$ 37.56 billion), South America ( $n=103$; US $\$ 1.74$ billion), and Oceania ( $n=571$; US $\$ 17.59$ billion) (Fig. 2 ). Regionally diverse or unspecified costs accumulated to a total of US\$ 116.43 billion $(n=104)$.

\section{Economic costs per taxonomic group}

Overall, the compiled data covered 177 species from 75 families (Online Resource 1, Tab_4 "SummaryCostPerSpecies"). The majority of costs within the expanded database ( $n=3,580 ;$ US 1.15 trillion) were caused by Insecta (arthropods). These were followed by costs for Secernentea (nematodes) ( $n=300$; US $\$ 0.01$ billion) and Arachnida (arthropods) ( $n=58$; US $\$ 9.94$ billion). Costs inferred to Gastropoda (molluscs) ( $n=26$; US $\$ 116.72$ million), and Rhabditophora (platyhelminths) ( $n=1$; US\$ 16.45 million) were much lower. Cost attributed to multiple taxonomic groupings ("Diverse/Unspecified") amounted to US\$ 51.26 billion $(n=40)$.

\section{Type of economic costs and activity sectors affected}

The majority of reported costs resulted from direct damages or resource losses ( $n=1896$; US $\$$ 960.94 billion) (Fig. 3a). Comparably, only US\$ 43.87 billion $(n=1679)$ was directly spent on management interventions. Mixed costs contributed US $\$ 256.04$ billion $(n=430)$. Within the reported management interventions, US\$ 37.36 billion was spent on post-invasion management (e.g. control, eradication), but only US\$ 0.07 billion on pre-invasion management (e.g. biosecurity, surveillance). Remaining management spending was mixed in type or related to knowledge and funding.

According to reported data, the majority of terrestrial invertebrate costs affected the forestry $(n=692 ;$ US\$ 385.46 billion) and agriculture sectors ( $n=1070$; US $\$ 350.59$ billion); mostly driven by insects, followed by diverse/unspecified taxa, Secernentea (nematodes) and Arachnida (Fig. 3b). Insects also affected 
other sectors (e.g., authorities-stakeholders, public and social welfare, and mixed categories), while Secernentea impacted forestry primarily, and other taxa mostly affected agriculture. Other sectors much impacted by the costs of invasive terrestrial invertebrates were authorities-stakeholders $(n=1728$; US $\$$ 94.12 billion), and public and social welfare ( $n=98$; US $\$ 35.55$ billion). Comparably lower reported costs were inferred to the environment ( $n=38$; US $\$ 2.32$ billion) and health sectors ( $n=19$; US 0.05 billion). Mixed costs, i.e. costs not impacting specific sectors and/or impacted multiple sectors, contributed US\$ 392.71 billion $(n=360)$.

\section{Annual cost accumulation}

The estimated US\$ 1.26 trillion over the period of 1960 to 2020 resulted in an average of US\$ 20.67 billion per year over the entire period. However, the predicted trend of cost accumulations from 1960 to 2020 differed among regression models (Fig. 4 ). Ordinary least squares (OLS), robust and quantile regressions revealed that economic costs incurred by invasive terrestrial invertebrates continuously increased over the period 1960-2020. The OLS regression estimated the costs of invasive species in 2020 at between US\$ 82.22 and 88.91 billion (Fig. 4a), while it was estimated at between US\$ 85.56 and 441.96 billion by the robust regression (Fig. 4b). Quantile regression revealed increased cost amplitudes over time (Fig. 4c). Multivariate adaptive regression splines, which showed the best fit as revealed by the RMSE of the calibrated models (Online Resource 2), suggested costs peaking at US\$ 57.44 billion in 2003, before decreasing to a total of US\$ 5.36 billion in 2020 (Fig. 4d). The GAM, with the second lowest RMSE, predicted a ten-fold increase in costs of invasive terrestrial invertebrates over the 1960-2020 period and an average cost of US\$ 17.22 billion in 2020 (Fig. 4e).

\section{Discussion}

Global economic costs attributable to invasive terrestrial invertebrates were found to sum to US\$1.26 trillion in the present study over the last six decades, with an average reported cost of US\$ 21 billion per year since 1960, with an exponential increase since 1960 and substantial fluctuations across time. These costs show that invasive terrestrial invertebrates have placed tremendous pressure on the global economy across a range of sector and cost categories in recent decades. There were clear geographic biases observed towards North America regarding the costs incurred by terrestrial invertebrates, and taxonomic biases, particularly towards invasive insects in North America and Asia. These findings mean that the reported figures are likely underestimations of costs in other regions, and missing many terrestrial invertebrate invasions where costs are unreported. This is further compounded by a lack of cost reporting on different scales, with few studies within invasion science reporting monetary costs within known areas largely impacted by invaders (Crystal-Ornelas and Lockwood 2020). Costs were driven primarily by resource damages or losses, and were unevenly distributed across the full range of economic sectors, with agriculture and forestry sectors disproportionately reporting the highest costs, but with many costs inferred to mixed sectors. Moreover, our examination of cost accumulations through time showed a general pattern of increase temporally. However, the best-fitting model (MARS) projected a decrease in 
recent years, which might reflect sensitivity to incomplete data, given time lags between cost incurrence and reporting. Indeed, as the rate of terrestrial invertebrate invasions continues to increase (Seebens et al. $2017,2020)$, it is conversely probable that there will be further concurrent increases in economic costs.

In a regional context, costs incurred in North America dominated, potentially indicating a larger scientific effort, or overall stronger awareness of invasive species economic costs in that region. Alternatively, higher resource damages and losses in North America may be due to more assets likely to be damaged. Indeed, specific species like the gypsy moth Lymantria disparand the emerald ash borer Agrilus planipennis are well known for their costly impacts in North America (Régnière et al. 2008; Herms and McCullough 2014). On the other hand, the low number of cost entries and reports for countries such as Australia is surprising, despite the known damages of invasive terrestrial invertebrates to the agriculture sector there (e.g. Baker 2008). This is even more surprising when considering the biodiversity threats posed by invasive ants in this country (Lach and Thomas 2008; Wylie and Janssen-May 2016), and the monetary expenditures associated with their management (Hoffmann and Broadhurst 2016). Another striking example is the complete absence of the lesser mealworm Alphitobius diaperinus from our database, despite the massive efforts that are being deployed worldwide for combating the pullulations of this poultry house pest (Wolf et al. 2015). In sum, our findings raise questions about the lack of cost estimations for invasive species and highlight geographic knowledge gaps. Our study urges the need for increased reporting of invasion costs generally, with stronger efforts being required for underrepresented regions and taxonomic groups.

Our average annual estimate since 1960 (US\$ 21 billion) is 8-times higher than the annual United Nations budget (2017; https://news.un.org/en/story/2017/12/640451-general-assembly-approves-54-billion-unbudget-next-two-years ). Moreover, our peak annual cost in 2013 (US\$ 57 billion) is even higher, similar to the entire GDP of rich countries such as Luxembourg (US\$ 62 billion in 2017). The reported economic costs of invasive insects alone amounted to a minimum of US\$ 70 billion per year (Bradshaw et al. 2016). Importantly, in contrast to that study, we did not include insects with an aquatic life stage or that are associated with water for reproduction or foraging. As aquatic invertebrates such as mosquitoes drive huge impacts, exceeding US\$ 100 billion since 1960 (Cuthbert et al. in press a), our costs would have been much higher with their inclusion, and would have likely matched those formerly reported in Bradshaw et al. (2016). Indeed, our average annual costs of wholly terrestrial insects alone was estimated to be higher than US\$ 18.35 billion in 2020 following linear models. Finally, some IAS insects have expanded rapidly in recent years, as is the case for example of the spotted wing Drosophila Drosophila suzukii, devastating cherries, plums and grapes in several European countries (Nikolouli et al. 2018). The rapidly growing outbreaks of this pest is associated with additional production costs and lower revenues for the producers (Knapp et al. 2020). While potentially highly significant, we only have 15 cost entries collected from nine distinct references for this pest insect. Similarly, the fall armyworm Spodoptera frugiperda, which is heavily impacting agriculture in Africa and Asia (Naganna et al. 2020; Tambo et al. 2020), has only 22 cost entries, again exemplifying the delay existing in between the observation of pullulations and pest damages and the publication of associated economic losses. 
There were marked differences in contributions among taxonomic groupings, with costs from insects dominating, and other groups contributing relatively little to cost totals. Yet, this result does not mean that costs attributed to other taxonomic groups are unimportant, but rather that their impacts relate less clearly to economic enterprises and less easy to quantify (e.g., insect impacts on agriculture and human health are well-known; Akiner et al. 2016; Sileshi et al. 2019), or that those groups are relatively less studied overall (e.g., invasive micro-invertebrates). For instance, relatively few costs were reported for invasive spiders. It is also the case for invasive snails and slugs and for invasive earthworms, all of which are particularly impactful species with relatively few to no reported costs. There are at least 175 species of terrestrial gastropods established outside of their native ranges (Capinha et al. 2015). Many of these are very damaging land snails, among which the two infamous carnivorous rosy wolfsnail (Euglandina rosea) and the giant African snail (Achatina fulica) which caused the extinction of many endemic snails on the islands of Hawaii, Tahiti, Moorea, and other Pacific islands (e.g., Davis-Berg 2012). The giant African snail is one of the largest land snails in the world, reaching up to $19 \mathrm{~cm}$ in length, a ferocious native snail predator and a vector of at least two human diseases (Meyer et al. 2008). Given the damage these and a dozen other species do, and the existence of management programs developed to control them, it is surprising that no more costs are recorded for gastropods. Similarly, over 100 alien species of earthworms have been documented globally (Hendrix et al. 2006), and they have now spread into habitats where few or no native earthworms exist, such as North America (McCay and Scull 2019), the Taiga region in Russia and the coniferous forests of Scandinavia (Hendrix et al. 2006), which has lacked these species since the last glacial age. As they are underground species, invasive earthworms have been mostly neglected until very recently, but since they are ecosystem engineers, their impacts are believed to be important (Migge-Kleian et al 2006). Yet, economic costs are absent from recorded invasions for this group. Other groups of invasive terrestrial invertebrates are likewise entirely or largely lacking.

Conversely, the high relative contribution of invasive insect costs may simply relate to that group being one of the most diverse globally, both in terms of overall biodiversity and invasive species richness (Finlay et al. 2006; Roques et al. 2009). Economic costs, in particular non-market costs of environmental degradation, are also more challenging to quantify with certainty (Epanchin-Niell 2017). Likewise, certain direct monetary losses attributed to IAS are more difficult to ascertain, as evidenced for non-native earthworms (Addison 2009) or insects (Holmes et al. 2009) invading forests. This difficulty results from the multiple dimensions of the effects caused by IAS, in addition to the valuation of ecological consequences in monetary units which remains often difficult. However, other studies have highlighted that reported economic costs usually concerned less than $1-10 \%$ of invasive alien species (e.g., Bradshaw et al. in press; Cuthbert et al. in press b; Haubrock et al. in press b; Liu et al. in press; Renault et al. in press) and this likely also applies to insects. Future studies should seek to address this knowledge gap using a range of improved assessment measures and taxa (Hanley and Roberts 2019).

Within insects, three groups dominated the costs: Erebidae (US\$ 126 billion), Cerambycidae (longhorn beetles; a known pest impacting forestries, agricultural and forestry pests; US\$ 112 billion), and Noctuidae (owlet moths; US\$ 106 billion). As voracious defoliators, moth caterpillars are major pests in forests (Haynes et al. 2014), and are also great threats to production of cotton (Rajendran et al. 2018) 
and food (Vreysen et al. 2007, 2016). The majority of costs in the present study were attributed to direct resource damages or losses, which clearly emanate principally from agricultural and forestry enterprises. In contrast, spending from health sector-related damages and losses was relatively minor. This is surprising, as ticks and dust mites are well known vectors of arthropod borne diseases, and can also cause allergies (Marcondes and Dantas-Torres 2017). The minimal levels of control-related expenditure is additionally concerning given that preventative measures (i.e., biosecurity practices) can prove to be far more economical than ongoing control measures, because it is comparatively challenging to eradicate or manage invaders following establishment (Leung et al. 2002).

We identified a general increase in average annual reported costs since 1960, reflecting the increase in terrestrial invertebrate introductions described by Roques et al. (2009) and Seebens et al. (2017), with some models suggesting a cost reduction in recent years. In turn, this highlights the urgent need to improve current management and control, but also prevention efforts and cost reporting. Indeed, as globalization ensues and greater interconnectedness facilitates introductions from novel non-native source pools, the numbers and costs of invasive terrestrial invertebrates is expected to increase owing to trade pathways such as shipping and aviation (Seebens et al. 2018). Furthermore, range expansion of invertebrate invaders can be expected to occur with climate change, as Bellard et al. (2013) previously projected an average net increase in the range expansion of non-native terrestrial invertebrates of $18 \%$ by 2050, with likely increasing costs.

In conclusion, the economic costs of invasive terrestrial invertebrates presented here should be an incentive for decision makers to invest in preventing the arrival and spread of such species. Furthermore, the relatively high costs reported in North America and distinct lack of cost information in other regions underlines both the massive underestimate we present here and the need for further cost estimation efforts globally. The same can be claimed for the taxonomic representation in recorded costs. Our study highlights the need for national and regional authorities to produce more structured reporting of costs in order to improve the accuracy of these estimates. In addition, the relatively small amounts spent on control and prevention strategies directly, compared to costs of damage incurred from well-established invader populations, justifies greater investment in preventative biosecurity protocols. Given current and future invasion rates (Seebens et al. 2017, 2020), and the likelihood that known costs are broadly underestimated and poorly monetized, we expect that further examination will reveal that the costs of invasive terrestrial invertebrates are substantially higher than what we have presented here.

\section{Declarations}

\section{Funding}

The authors acknowledge the French National Research Agency (ANR-14-CE02-0021) and the BNPParibas Foundation Climate Initiative for funding the InvaCost project that allowed the construction of the InvaCost database. The present work was conducted following a workshop funded by the AXA Research Fund Chair of Invasion Biology and is part of the AlienScenario project funded by BiodivERsA and 
Belmont-Forum call 2018 on biodiversity scenarios. RNC is funded by a fellowship from the Alexander von Humboldt Foundation. CC was supported by Portuguese National Funds through Fundação para a Ciência e a Tecnologia (CEECIND/02037/2017; UIDB/00295/2020 and UIDP/00295/2020). DR is funded by the French Polar Institute Paul-Emile Victor (Project IPEV 136 'Subanteco') and by the ASICS project (ANR-20-EBI5-0004, BiodivERsA, BiodivClim call 2019-2020); he also thanks InEE-CNRS who supports the national network 'Biological Invasions' (Groupement de Recherche InvaBio, 2014-2022). AMK was supported by the NSF Macrosystems Biology program under grant 1834548. Funds for EA contract comes from the AXA Research Fund Chair of Invasion Biology of University Paris Saclay.

Acknowledgements

We thank Boris Leroy and Christophe Diagne for helpful suggestions while we were conducting the statistical analyses.

Conflicts of interest/Competing interests

The authors declare that there are no conflicting or competing interests.

Availability of data and material

Underlying data are publicly available in an online repository

(https://doi.org/10.6084/m9.figshare.12668570) and in the Online Resource 1.

Code availability

Not applicable.

Authors' contributions

PJH and RNC analysed the data. DR, EA, RNC and PJH led the writing with contributions from all other authors. EA and FC produced the underlying database and helped with all parts of the manuscript.

Ethics approval

Not applicable.

Consent to participate

Not applicable.

Consent for publication

All authors have seen and approved the manuscript and have consented for publication.

\section{References}


Akiner MM, Demirci B, Giorgi Babuadze VR, Schaffner F (2016). Spread of the invasive mosquitoes Aedes aegypti and Aedes albopictus in the Black Sea region increases risk of chikungunya, dengue, and Zika outbreaks in Europe. PLoS Negl Trop Dis 10(4).

Addison JA (2009) Distribution and impacts of invasive earthworms in Canadian forest ecosystems. Biol Invasions 11:59-79.

Angulo E, Diagne C, Ballesteros-Mejia L, Akulov E, Dia CAKM, Adamjy T, Banerjee A-K, Capinha C, Duboscq VG, Dobigny G., Golivets M, Heringer G, Haubrock P, Kirichenko N, Kourantidou M, Liu C, Nuñez M, Renault D, Roiz D, Taheri A, Watari Y, Xiong W, Courchamp F (2021) Non-English languages enrich scientific knowledge: the example of economic costs of biological invasions. Sci Total Environ, In Press.

Baker GH (2008) The population dynamics of the mediterranean snails Cernuella virgata, Cochlicella acuta (Hygromiidae) and Theba pisana (Helicidae) in pasture-cereal rotations in South Australia: a 20year study. Aust J Exp Agr 48(12):1514-1522.

Bebber DP, Ramotowski MA, Gurr SJ (2013) Crop pests and pathogens move polewards in a warming world. Nat Clim Change 3(11):985.

Bellard C, Thuiller W, Leroy B, Genovesi P, Bakkenes M, Courchamp F (2013) Will climate change promote future invasions? Glob Change Biol 19(12):3740-3748.

Bertelsmeier C, Blight O, Courchamp F (2015) Invasions of ants (Hymenoptera: Formicidae) in light of global climate change. Myrmecol News 22:25-42.

Blackburn TM, Bellard C, Ricciardi A (2019) Alien versus native species as drivers of recent extinctions. Front Ecol Environ 17(4):203-207

Bradshaw CJ, Leroy B, Bellard C, Roiz D, Albert C, Fournier A, Courchamp F (2016) Massive yet grossly underestimated global costs of invasive insects. Nat Commun 7(1):1-8.

Bradshaw CJ, Haubrock P, Cuthbert RN, Diagne C, Leroy B, Andrews L, Page B, Cassey P, Hoskins A, Courchamp F (2021) Comprehensive assessment of the economic costs of invasive species in Australia. NeoBiota. In press.

Buczkowski G, Bertelsmeier C (2017) Invasive termites in a changing climate: A global perspective. Ecol Evol 7(3):974-985.

Caffrey JM, Baars JR, Barbour JH, Boets P, Boon P, Davenport K, Gross J (2014) Tackling invasive alien species in Europe: the top 20 issues. Manag Biol Invasions 5(1):1.

Capinha C, Essl F, Seebens H, Moser D, Pereira HM (2015) The dispersal of alien species redefines biogeography in the Anthropocene. Science 348:1248. 
Cowie RH, Hayes KA, Tran CT, Meyer III WM (2008) The horticultural industry as a vector of alien snails and slugs: widespread invasions in Hawaii. Int J Pest Manag 54(4):267-276.

Crystal-Ornelas R, Lockwood JL (2020) The 'known unknowns' of invasive species impact measurement. Biol Invasions 22(4):1513-1525.

Cuthbert RN, Pattison Z, Taylor NG, Verbrugge L, Diagne C, Ahmed DA, Leroy B, Angulo E, Briski E, Capinha C, Catford JA, Dalu T, Essl F, Gozlan RE, Haubrock PJ, Kourantidou M, Kramer AM, Renault D, Wasserman RJ, Courchamp F (2021a) Global economic costs of aquatic invasive alien species. Sci Total Environ. In press.

Cuthbert RN, Bartlett AC, Turbelin A, Haubrock PJ, Diagne C, Pattison Z, Courchamp F, Catford J (2021b) Economic costs of biological invasions in the United Kingdom. NeoBiota. In press

Davis-Berg EC (2012) The predatory snail Euglandina rosea successfully follows mucous trails of both native and non-native prey snails. Invertebr Biol 131:1-10.

Diagne C, Leroy B, Gozlan R, Vaissière A, Nunninger L, Assailly C, Roiz D, Jourdain F, Jarić I, Courchamp F (2020) INVACOST: a public database of the global economic costs of biological invasions worldwide. Sci Data 7:277.

Early R, Bradley BA, Dukes JS, Lawler JJ, Olden JD, Blumenthal DM, Sorte CJ (2016) Global threats from invasive alien species in the twenty-first century and national response capacities. Nat Commun 7(1):1-9.

Epanchin-Niell RS (2017) Economics of invasive species policy and management. Biol Invasions 19:3333-3354.

Finlay BJ, Thomas JA, McGavin GC, Fenchel T, Clarke RT (2006) Self-similar patterns of nature: insect diversity at local to global scales. Proc Royal Soc B 273(1596):1935-1941.

Hanley N, Roberts M (2019) The economic benefits of invasive species management. People and Nature 1:124-137.

Haubrock PJ, Turbelin AJ, Cuthbert RN, Novoa A, Taylor NG, Angulo E, Ballesteros-Mejia L, Bodey TW, Capinha C, Diagne C, EssI F, Golivets M, Kirichenko N, Kourantidou M, Leroy B, Renault D, Verbrugge L, Courchamp F (2021a) Costs of invasive species in Europe. Neobiota. In press

Haubrock PJ, Cuthbert RN, Sundermann A, Diagne C, Golivets M, Courchamp F (2021b) Economic costs of invasive species in Germany. Neobiota. In press.

Haynes KJ, Allstadt AJ, Klimetzek D (2014) Forest defoliator outbreaks under climate change: effects on the frequency and severity of outbreaks of five pine insect pests. Glob Change Biol 20:2004-2018. 
Hendrix PF (2006) Biological invasions belowground-earthworms as invasive species. Biol Invasions 8:1201-1204.

Heringer G, Angulo E, Ballesteros-Mejia L, Capinha C, Courchamp F, Diagne C, Duboscq-Carra V, Nuñez M, Zenni R (2021) The economic costs of biological invasions in Central and South America: a first regional assessment. NeoBiota. In press.

Herms DA, McCullough DG (2014) Emerald ash borer invasion of North America: history, biology, ecology, impacts, and management. Annu Rev Entomol 59:13-30.

Hoagland P, Jin D (2006) Science and economics in the management of an invasive species. BioScience 56:931-935.

Hoffmann BD, Broadhurst LM (2016) The economic cost of managing invasive species in Australia. NeoBiota 31:1.

Holmes TP, Aukema JE, Von Holle B, Liebhold A, Sills E (2009) Economic impacts of invasive species in forests. Ann N Y Acad Sci 1162:18-38.

Holway DA, Lach L, Suarez AV, Tsutsui ND, Case TJ (2002) The causes and consequences of ant invasions. Annu Rev Ecol Evol Syst 33(1): 181-233.

Hulme PE (2014) Invasive species challenge the global response to emerging diseases. Trends Parasitol 30(6):267-270.

Kettunen M, Genovesi P, Gollasch S, Pagad S, Starfinger U et al (2009) Technical support to EU strategy on invasive species (IAS): assessment of the impacts of IAS in Europe and the EU (final module report for European commission), Serv contract 070307/2007/483544/MAR/B2, Inst Eur Environ Policy (IEEP), Brussels.

Knapp L, Mazzi D, Finger R (2020) The economic impact of Drosophila suzukii: perceived costs and revenue losses of Swiss cherry, plum and grape growers. Pest Manag Sci.

Kourantidou M, Cuthbert RN, Haubrock P, Novoa A, Taylor N, Leroy B, Capinha C, Renault D, Angulo E, Diagne C, Courchamp F (2021) Economic costs of invasive alien species in the Mediterranean basin. Neobiota. In press.

Lach L, Thomas ML (2008) Invasive ants in Australia: documented and potential ecological consequences. Aust J Entomol 47:275-288.

Lebouvier M, Lambret P, Garnier A., Convey P, Frenot Y, Vernon P, Renault D (2020) Spotlight on the invasion of a carabid beetle on an oceanic island over a 105-year period. Sci Rep 10:17103. 
Leroy B, Kramer A, Vaissière A-C, Courchamp F, Diagne C (2020) Analysing global economic costs of invasive alien species with the invacost R package. biorXiv, https://doi.org/10.1101/2020.12.10.419432.

Leung B, Lodge DM, Finnoff D, Shogren JF, Lewis MA, Lamberti G (2002) An ounce of prevention or a pound of cure: bioeconomic risk analysis of invasive species. Proc Royal Soc B 269(1508):2407-2413.

Liebhold AM, Kean JM (2019) Eradication and containment of non-native forest insects: successes and failures. J Pest Sci 92(1):83-91.

Liu X, Blackburn TM, Song T, Wang X, Huang C, Li Y (2020) Animal invaders threaten protected areas worldwide. Nat Commun 11(1):1-9.

Liu C, Diagne C, Angulo E, Banerjee A, Chen Y, Cuthbert NR, Haubrock JP, Kirichenko N, Pattison Z, Watari $\mathrm{Y}$, Xiong W, Courchamp F (2021) Economic costs of biological invasions in Asia. NeoBiota. In press.

Lodge DM, Simonin PW, Burgiel SW, Keller RP, Bossenbroek JM, Jerde CL, Chadderton WL (2016) Risk analysis and bioeconomics of invasive species to inform policy and management. Annu Rev Environ Resour 41:453-488.

Lovell SJ, Stone SF, Fernandez L (2006) The economic impacts of aquatic invasive species: a review of the literature. Agric Resour Econ Rev 35(1):195-208.

Marbuah G, Gren IM, McKie B (2014) Economics of harmful invasive species: a review. Diversity 6(3):500523.

Marcondes CB, Dantas-Torres F (2017) Diseases caused by Acari (Ticks and Mites). In: Marcondes C (ed) Arthropod Borne Diseases. Springer, Cham, pp 537-548. https://doi.org/10.1007/978-3-319-13884-8_34

McCay TS, Scull P (2019) Invasive lumbricid earthworms in northeastern North American forests and consequences for leaf-litter fauna. Biol Invasions 21:2081-2093.

Medlock JM, Hansford KM, Versteirt V, Cull B, Kampen H, Fontenille D, Schaffner F (2015) An entomological review of invasive mosquitoes in Europe. Bull Entomol Res 105(6):637-663.

Meyer WM III, Hayes KA, Meyer AL (2008) Giant African snail, Achatina fulica, as a snail predator. Am Malacol Bull 24:117-119.

Migge-Kleia S, McLean MA, Maerz JC, Heneghan L (2006) The influence of invasive earthworms on indigenous fauna in ecosystems previously uninhabited by earthworms. Biol Invasions 8:1275-1285.

Naganna R, Jethva DM, Bhut JB, Wadaskar PS, Kachot A (2020) Present status of new invasive pest fall armyworm, Spodoptera frugiperda in India: A review. J Entomol Zool Stud 8(2):150-156.

Nikolouli K, Colinet H, Renault D, Enriquez T, Mouton L, Gibert P, Sassu F, Cáceres C, Stauffer C, Pereira R, Bourtzis K (2018) Sterile insect technique and Wolbachia symbiosis as potential tools for the control of 
the invasive species Drosophila suzukii. Pest Science 91:489-503.

Paini DR, Sheppard AW, Cook DC, De Barro PJ, Worner SP, Thomas MB (2016). Global threat to agriculture from invasive species. Proc Natl Acad Sci 113(27):7575-7579.

Pejchar L, Mooney HA (2009) Invasive species, ecosystem services and human well-being. Trends Ecol Evol 24(9):497-504.

Pimentel D, Lach L, Zuniga R, Morrison D (2000) Environmental and economic costs of nonindigenous species in the United States. BioScience 50(1):53-65.

Pimentel D, Hepperly P, Hanson J, Douds D, Seidel R (2005) Environmental, energetic, and economic comparisons of organic and conventional farming systems. BioScience 55(7):573-582.

R Core Team (2020) R: A language and environment for statistical computing. R Foundation for Statistical Computing, Vienna, Austria. URL https://www.R-project.org/.

Rajendran TP, Birah A, Burange PS (2018) Insect pests of cotton. In: Omkar (ed) Pests and their management. Springer, Singapore, pp 361-411. https://doi.org/10.1007/978-981-10-8687-8_11

Régnière J, Nealis V, Porter K (2008) Climate suitability and management of the gypsy moth invasion into Canada. In: Langor DW, Sweeney J (ed) Ecological impacts of non-native invertebrates and fungi on terrestrial ecosystems. Springer, Dordrecht, pp 135-148.

Renault D, Leroy B, Manfrini E, Diagne C, Ballesteros-Mejia L, Angulo E, Courchamp F (2021) Biological invasions in France: Alarming costs and even more alarming knowledge gaps. NeBiota. In press.

Rico-Sánchez AE, Sundermann A, López-López E, Torres-Olvera MJ, Mueller SA, Haubrock PJ (2020) Biological diversity in protected areas: Not yet known but already threatened. Glob Ecol Conserv e01006.

Roques A, Rabitsch W, Rasplus JY, Lopez-Vaamonde C, Nentwig W, Kenis M (2009) Alien terrestrial invertebrates of Europe. In DAISIE (ed) Handbook of alien species in Europe. Invading Nature - Springer Series in Invasion Ecology, vol 3, Springer, Dordrecht, pp 63-79.

Roques A (2010) Alien forest insects in a warmer world and a globalised economy: impacts of changes in trade, tourism and climate on forest biosecurity. N Z J For Sci 40:S77-S94.

Seebens H, Blackburn TM, Dyer EE, Genovesi P, Hulme PE, Jeschke JM, Bacher S (2017) No saturation in the accumulation of alien species worldwide. Nat Commun 8(1):1-9.

Seebens H, Blackburn TM, Dyer EE, Genovesi P, Hulme PE, Jeschke JM, Ansong M (2018) Global rise in emerging alien species results from increased accessibility of new source pools. Proc Natl Acad Sci 115(10):E2264-E2273. 
Seebens H, Bacher S, Blackburn TM, Capinha C, Dawson W, Dullinger S, Genovesi P, Hulme PE, van Kleunen M, Kühn I, Jeschke JM, Lenzner B, Liebhold AM, Pattison Z, Pergl J, Pyšek P, Winter M, EssI F (2020) Projecting the continental accumulation of alien species through to 2050. Glob Change Biol $0(00)$ : $1-13$.

Sileshi GW, Gebeyehu S, Mafongoya P (2019) The threat of alien invasive insect and mite species to food security in Africa and the need for a continent-wide response. Food Security 11:763-775.

Sugiura S (2010) Prey preference and gregarious attacks by the invasive flatworm Platydemus manokwari. Biol Invasions 12:1499-1507.

Tambo JA, Day RK, Lamontagne-Godwin J, Silvestri S, Beseh PK, Oppong-Mensah B, Phiri NA, Matimelo M (2020) Tackling fall armyworm (Spodoptera frugiperda) outbreak in Africa: an analysis of farmers' control actions. Int J Pest Manag 66(4):298-310.

Vinson SB (1997) Invasion of the red imported fire ant: spread, biology and impact. Am Entomol 43:2339.

Vreysen MJB, Robinson AS, Hendrichs J (2007) Area-wide control of insect pests: from research to field implementation. Springer, Dordrecht.

Vreysen MJB, Klassen W, Carpenter JE (2016) Overview of technological advances toward greater efficiency and efficacy in sterile insect-inherited sterility programs against moth pests. Fla Entomol 99:112.

Wolf J, Potrich M, Lozano ER, Gouvea A, Pegorini CS (2015) Combined physical and chemical methods to control lesser mealworm beetles under laboratory conditions. Poultry Science 94(6):1145-1149.

Wong MK, Guénard B, Lewis OT (2020) The cryptic impacts of invasion: functional homogenization of tropical ant communities by invasive fire ants. Oikos 129:585-597.

Wylie FR, Janssen-May S (2016) Red imported fire ant in Australia: What if we lose the war? Ecol Manag Restor 18:32-44.

\section{Figures}




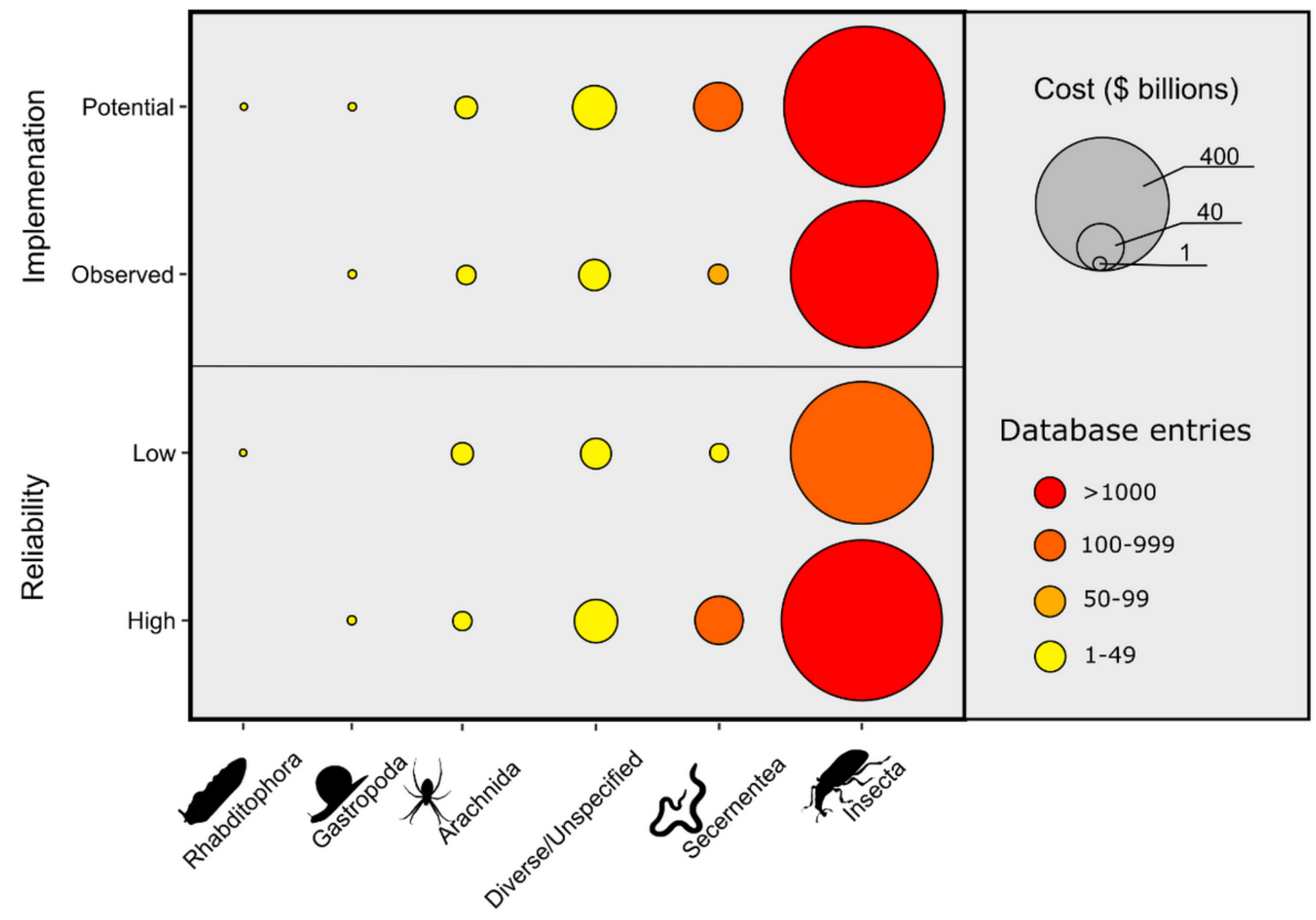

Figure 1

Global recorded costs incurred by terrestrial invertebrates worldwide over the period 1960-2020 according to cost implementation nature (potential versus observed costs) and method reliability (low versus high). Distinct circle sizes represent the different monetary costs incurred by invertebrate IAS, as captioned by the grey embedded circles at the top right of the figure. The colors of the circles represent the number of cost entries for each terrestrial invertebrate taxa, as captioned at the bottom left of the figure. 


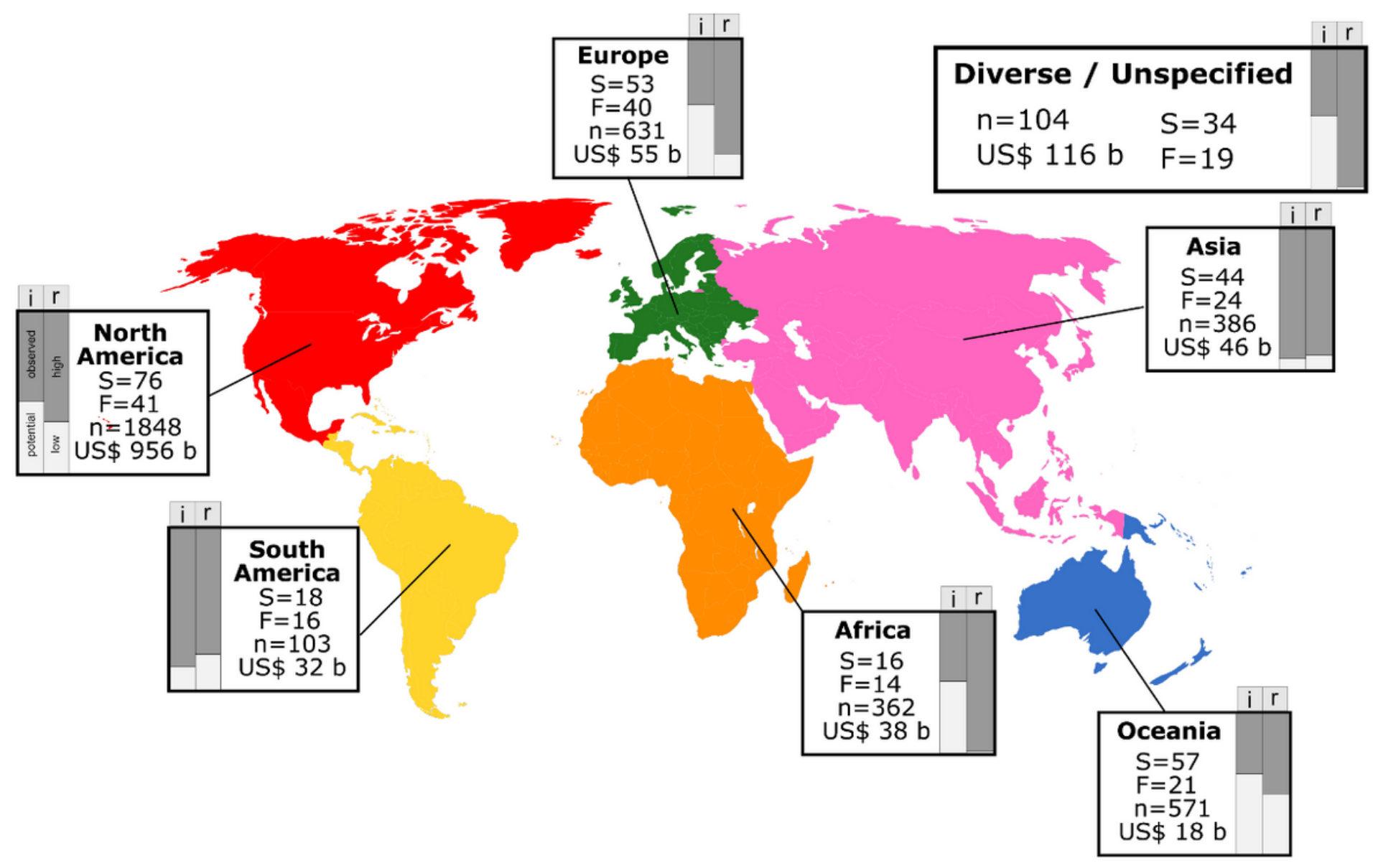

Figure 2

Global costs of recorded terrestrial invertebrates according to affected geographic regions. S: number of species; F: number of families; n: number of entries in the expanded dataset; b: billion; i: implementation method reporting whether the cost is observed (dark grey bar) or potential (light grey bar); r: reliability of the costs estimate (high: dark grey bar; or low: light grey bar). Note: The designations employed and the presentation of the material on this map do not imply the expression of any opinion whatsoever on the part of Research Square concerning the legal status of any country, territory, city or area or of its authorities, or concerning the delimitation of its frontiers or boundaries. This map has been provided by the authors. 
(a) Cost type

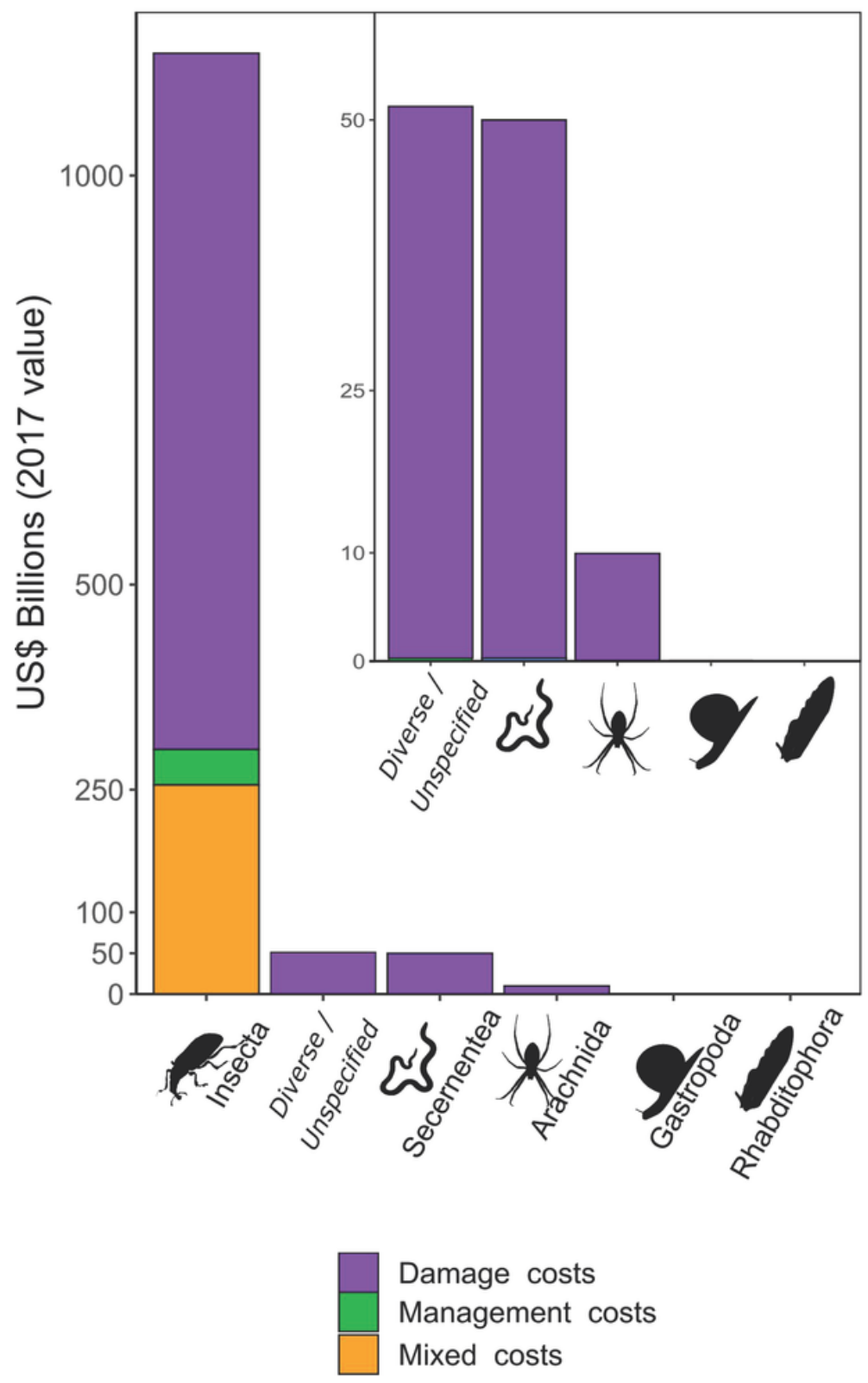

(b) Impacted sector

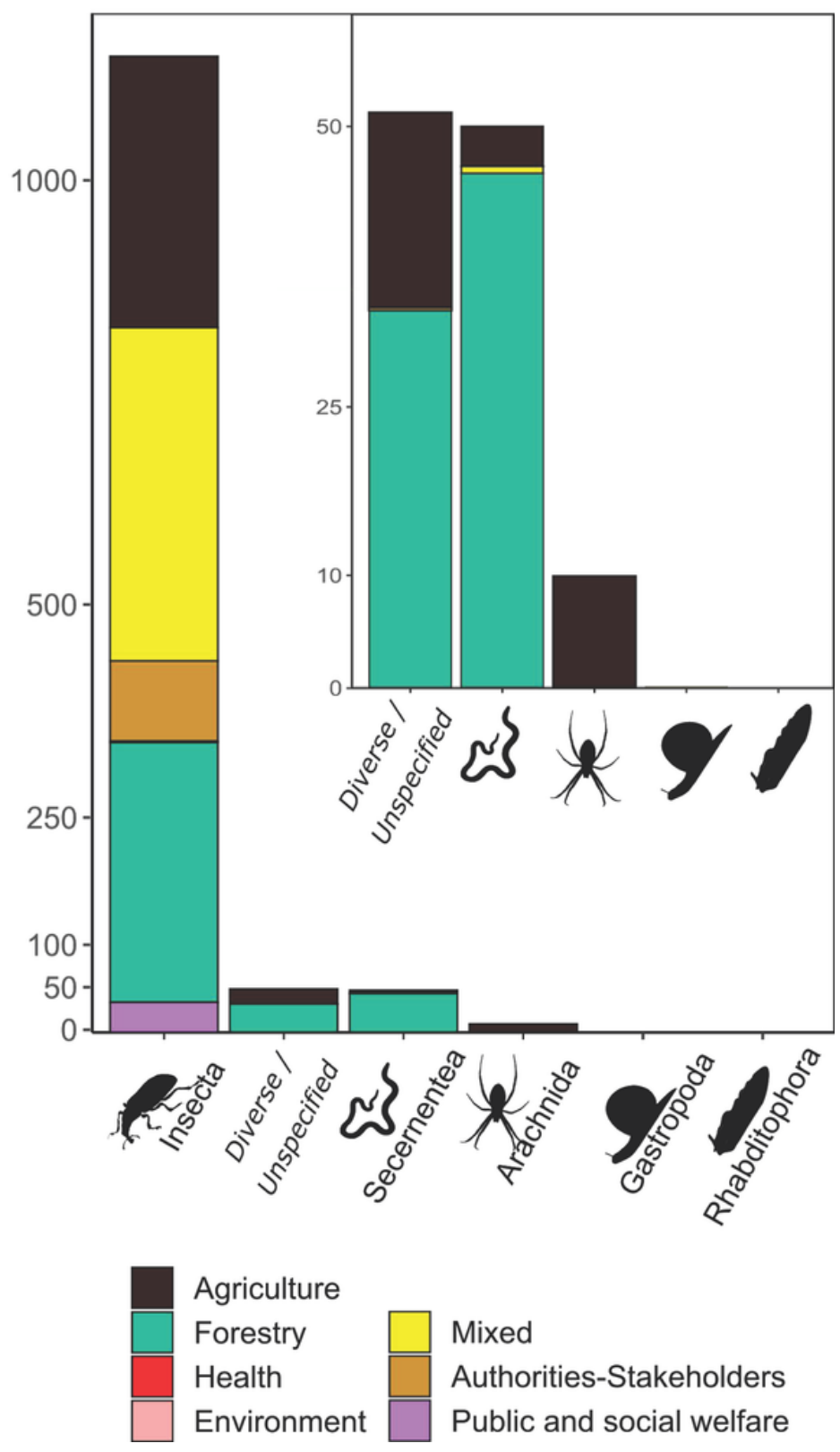

Figure 3

Global costs of recorded invertebrate taxa according to (a) cost types and (b) impacted sectors with reference to taxonomic groups. Inset graphs correspond to the categories with lower values. 
(a)

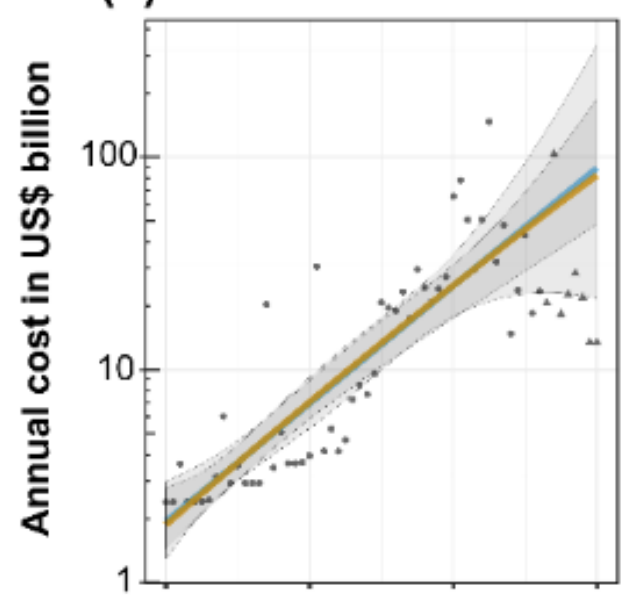

(c)

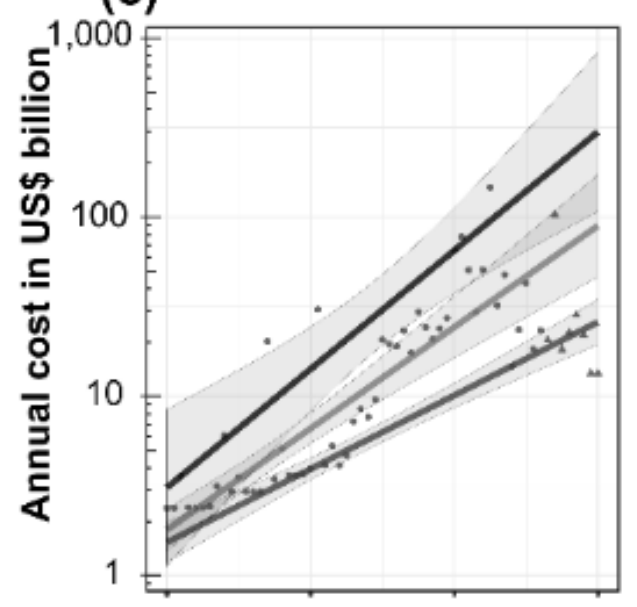

(e)

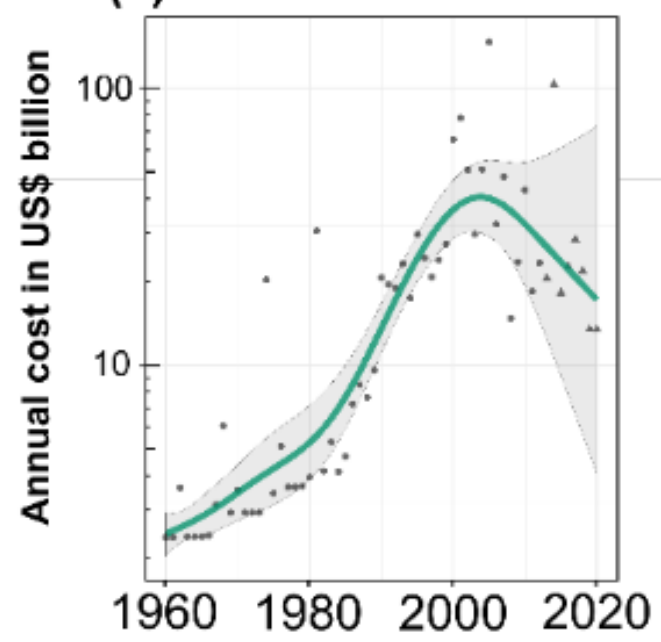

(b)

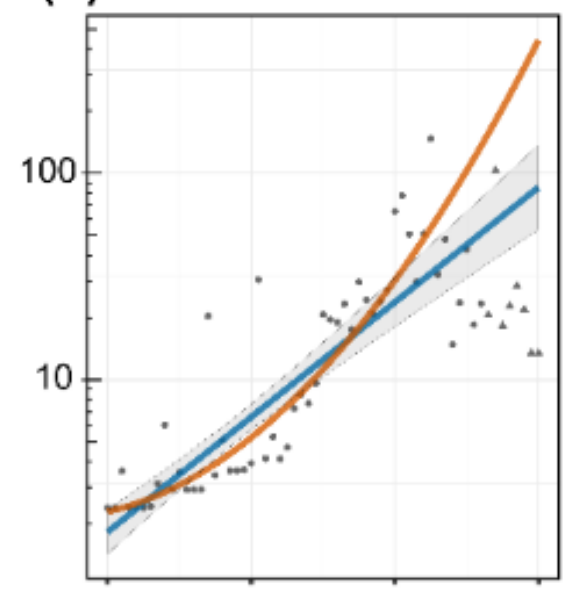

(d)

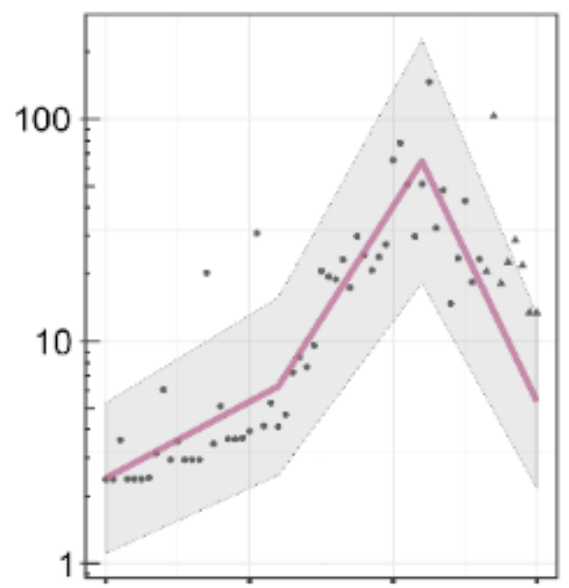

1960198020002020

\section{Figure 4}

Annual costs of terrestrial invertebrates across a range of modelling techniques between $1960-2020$ :

(a) linear regression (linear: blue; quadratic: orange), (b) robust regression (linear: blue; quadratic: orange),

(c) quantile regression (1 st quantile: light grey; 5th quantile: grey; 9th quantile: dark grey), (d) multivariate adaptive regression splines (MARS; purple), (e) generalized additive mModel (green). The grey points represent annual totals and triangles show excluded years owing to time lags (2013-2020). 


\section{Supplementary Files}

This is a list of supplementary files associated with this preprint. Click to download.

- OnlineResource1.xIsx

- OnlineResource2.docx 